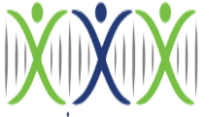

IRASD

Volume 9, Number 3, 2021, Pages 356-364

SCIENCES (PJHSS)

Journal Homepage:

https://journals.internationalrasd.org/index.php/pjhss

\title{
Exploration of Head Teachers' Attitudes towards Special Education Institutions' Internal Efficacy: A Mix Method Approach
}

\author{
Muhammad Zahid ${ }^{1}$, Samina Ashraf², Musarrat Jahan³ \\ ${ }^{1}$ Institute of Special Education, University of the Punjab, Lahore, Pakistan. \\ Email: mohzahidch@gmail.com \\ 2 Institute of Special Education, University of the Punjab, Lahore, Pakistan. \\ Email: samina.dse@pu.edu.pk \\ ${ }^{3}$ Assistant Professor, Department of Special Education, The Islamia University of Bahawalpur, Pakistan. \\ Email: mussarat.jahan@iub.edu.pk
}

\begin{tabular}{ll} 
ARTICLE INFO & \\
\hline Article History: & \\
Received: & October 08, 2021 \\
Revised: & December 04, 2021 \\
Accepted: & December 07, 2021 \\
Available Online: & December 09, 2021 \\
\hline Keywords: & \\
Attitudes & \\
Internal Efficacy & \\
Special education & \\
Head Teachers &
\end{tabular}

\section{ABSTRACT}

The present study is framed to explore the attitudes of rural and urban school head-teachers about their institutions' internal efficacy working in 8 divisions of Punjab. For this, 267 participants were selected as a sample; a random selection of 237 head-teachers and conveniently selected 30-parents from different divisions of Punjab. The researchers collected the data from the respondents in two parts. The quantitative data were collected from head-teachers of special education institutions through a standardized questionnaire having 11-factors: academics, community characteristics, financial, non-academic, parents' characteristics, principal characteristics, school characteristics, school climate, policies and organizational structure, students' characteristics items, teachers' characteristics and teachers learning opportunities. The qualitative data were collected from 30 parents through interview protocol. The researchers ensured the Cronbach's Alpha reliability of quantitative data that was .756. Collected quantitative data were analyzed using independent samples ttest whereas the qualitative data were analyzed through thematic analysis. The results of the quantitative data have shown the same attitudinal level of internal efficacy in rural and urban public-sector special schools. Moreover, the results of the qualitative part established that the majority of parents were satisfied from special schools' head-teachers managerial capabilities, attitudes towards parents, provision of curricular and co-curricular activities, special emphasis on parentsteachers meetings, and schools buildings.

(c) 2021 The Authors, Published by iRASD. This is an Open Access Article under the Creative Common Attribution Non-Commercial

Corresponding Author's Email: mussarat.jahan@iub.edu.pk

\section{Introduction}

Head-teachers' intentions towards institutions are important indicators for the progress of students, teachers, and parents. Their constructive attitudes towards institutional success play a significant role in this regard (Ismail et al., 2016). Attitudes are referred to as a stable construct consisting of cognitive, affective, and behavioral aspects (Bizer et al., 2003; Vaz et al., 2015). Links of attitudes are rooted in the work of Ajzen (1985) who put forward the concept of "attitudes" in his theory of planned behavior (TPB). Beliefs, attitudes, and behavioral intentions are the key aspects of TPB (Berger, 2020). Individual attitudes are based on three important aspects: cognitive; head teachers' beliefs on the importance and necessity indicators of educational institutions that how it would be beneficial and bring change in institutional physical, infrastructure, and environmental aspects. Affective aspects; make a favorable response towards abrupt change that is being seen by the head-teachers, especially the internal satisfaction/dissatisfaction about institutional modernization while behavioral 
aspects immediately react to change or against change (Ajzen, 1985; Berger, 2020; Kin \& Kareem, 2017).

Efficacy refers to the effectiveness of any individual, organization, institution, state, etc. It is also considered as the capability to complete assigned tasks on assigned goals. Literature reported that the concept of efficacy is rooted in the work of Bandura (1978). The author has worked on the concept of efficacy and made a significant contribution in this regard (Adu, 2010). Internal efficacy refers to one's internal beliefs about their potential to bring constructive change (Bandura, 2007). Institutional internal efficacy has a strong correlation with one of the stakeholders; head-teachers' (Zahid, 2020) performance. Head-teachers are playing an important role to enhance institutional internal efficacy. They focus on schools' infrastructure (Gil-Flores et al., 201parent-teacher meetings (Islam, 2019), schools better performance (Heiskala et al., 2021), formation of school management council (Kim, 2004), technological inclusion for students better achievements by the teachers (Hassan et al., 2021) and teachers training (Kulshrestha \& Pandey, 2013). That shows head-teachers' constructive attitudes towards adds in the institutional betterment.

Strong evidence-based literature existed on the applications of head-teachers' attitudes on measuring institutional internal efficacy (Adeyemi, 2012; Iqbal, 2012; Wasal, 2012; Yang, 2014; Yunas, 2014). Adeyemi and Adu (2012) structured quantitative research in Nigeria on a sample of 520 participants to explore the quality and internal efficacy of schools. The authors administered two instruments to collect the data from the respondents. The results of the research indicated that the head teachers' positive or negative attitudes were the best predictors of institutional efficacy. Avramidis and Norwich (2000) structured research to find out special education teachers' attitudes towards institutional efficacy. Data from the respondents collected through administering standardized instruments having three parts; age, managerial experience, school leadership. The results of the research indicated the headteachers' attitudes towards institutional efficacy may vary from time to time. As head-teachers gain more age and experience, it brings a positive and constructive attitudinal change in their behavior. Moreover, Praisner (2003) tried his best to explore the attitudes of head-teachers to the internal efficacy of institutions. Findings of the research revealed that head-teachers have positive attitudes towards institutional betterment, development, and student achievement. Head-teachers' pain and observation play important role in reducing students, teachers, and parents' stress in this regard.

Horegard al. (2018) make a significant contribution in investigating head-teachers' attitude towards special education institutional internal efficacy. The results of the research established a strong significant positive relationship between head-teachers' attitudes and institutional internal efficacy. Pakistani social scientists also significantly contributed to exploring the current status of special schools head-teachers' internal efficacy. Zahid and Ashraf (2020) conducted quantitative research in Lahore-Pakistan to measure the internal efficacy of special schools teachers working in public and private institutions on a sample of randomly selected 200 teachers. The result established the significant difference between public and private special schools head-teachers' attitudes on the institutions' internal efficacy. Doctoral research was conducted by the Yunas (2014) in the Khyber Pakhtunkhwa district of Pakistan on a sample of 434-respondents using a stratified random sampling technique. The results of the research explored that institutional efficacy was affected due to head-teachers attitudes, students' retention rate, students' absenteeism, high wastage of sources, teachers' poor training, and teachers' non-professional attitudes towards jobs. It is evident from the above discussion that the head-teachers are the main stakeholders of institutions and their attitudes, either positive or negative, have a strong contribution towards their institutions' internal efficacy.

In this light, the main purpose of the current research is to explore head-teachers' attitudes towards the internal efficacy of special educational institutions working in different divisions of Punjab. The current research questions guided the study are (i) Are the attitudes of rural and urban head teachers towards special education institutions' internal efficacy the same? And (ii) Are parents of special students satisfied with the performance-related behavior of the head-teachers? 


\section{Research Methodology}

The methodology is a combination of a conceptual framework, data collection techniques, and data analysis method that provides the basis of the study (Brown et al., 2008). Research methodology refers to a procedural arrangement in which research is carried out (Maxwell \& Loomis, 2003). The researcher applied QUANT \& QUAL research design to understand the objective and subjective reality of the world through multiple sets of data (Amaratunga et al., 2002; Best \& Kahn, 2006; Creswell \& Cresswell, 2018). Mix methods research design uses inductive and deductive methods to answer the same phenomena through multiple approaches (Johnson \& Onwuegbuzie, 2004; Johnson \& Christensen, 2016; Teddlie \& Yu, 2007).

\subsection{Population and Sample of the Research}

A well-defined and appropriate population is essential for educational research (Gay et al., 2006). The population of current research consisted of head-teachers working in the schools of Punjab and parents of special needs students. The sample of current research consisted of 267 respondents: 237 head teachers and 30 parents. The sample of the quantitative part consisted of 237 head-teachers randomly selected from 8 Division and the sample of qualitative part consisted of 30 parents of children with different disabilities. The researcher purposively selected parents from different districts; both from rural and urban public-sector special education schools for interview. The parents were selected to give an opinion about head-teachers' abilities and performance related to the internal efficacy of special education institutions.

Figure 1: Demographics of the sample of the study

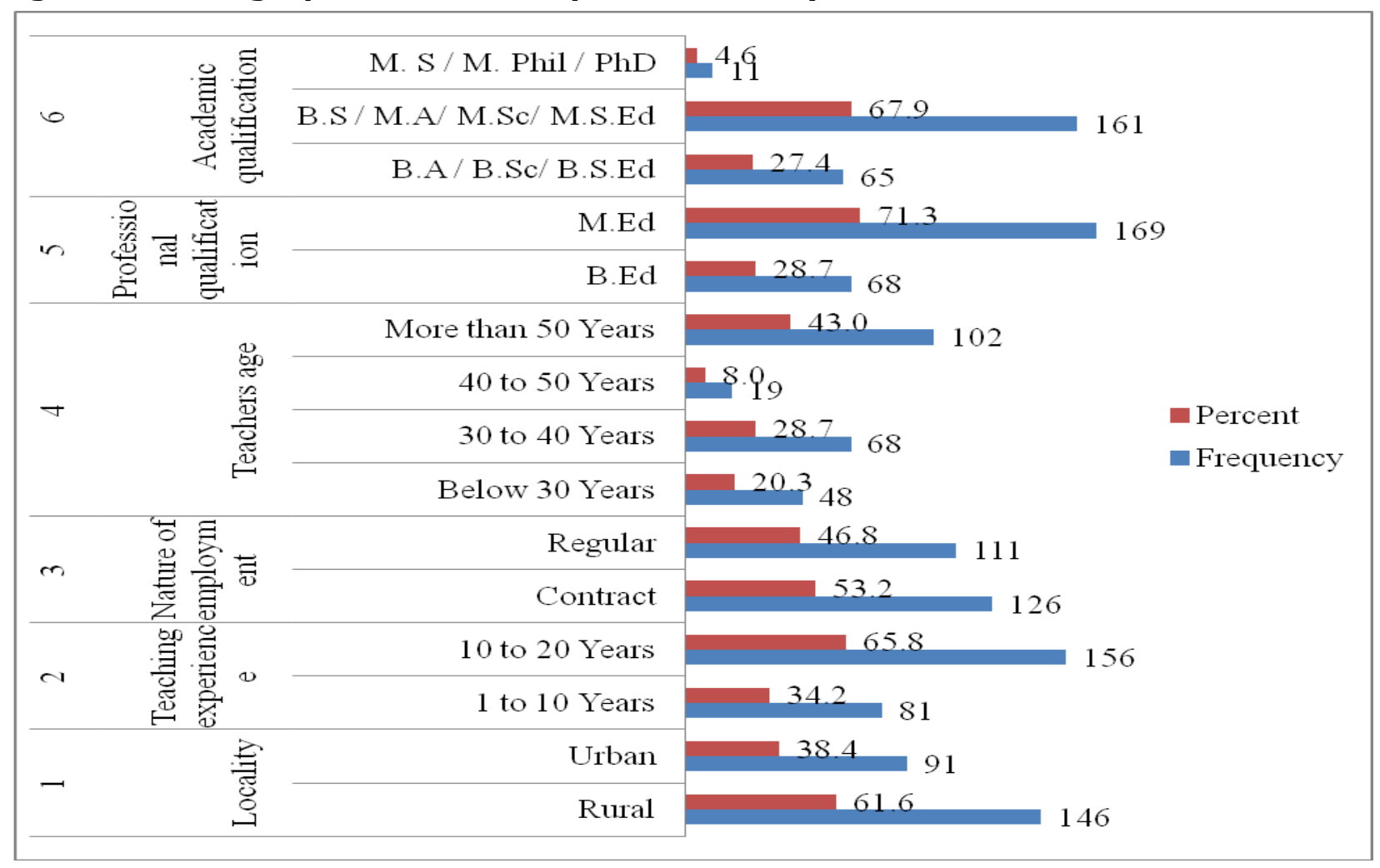

\subsection{Instrumentations}

The researcher administered two instruments in this research. A semi-structured interview protocol for 30-parents was used. The interview is used to collect information regarding an individual's knowledge, experiences, and practices on any phenomena. It is a way of assessing participants' perceptions for constructing reality (Punch, 2013; Best \& Kahn, 2006). For the quantitative part, the authors administered an adopted instrument from Yunas (2014) consisting of 11-factors; financial, students characteristics, parents characteristics, community characteristics, school characteristics, teachers characteristics, principal characteristics, teachers' learning opportunities, school climate policies, and organizational 
structure, academic and non-academic. The researchers assured the ecological validity and reliability of the adapted questionnaire. For this, the researchers piloted the standardized instrument on a small sample of the respondents to ensure Cronbach's alpha reliability, which is given below:

Table 1: Cronbach's Alpha Reliability statistics

\begin{tabular}{clcc}
\hline Sr \# & Factors name & N of Items & Cronbach's Alpha \\
\hline $\mathbf{1}$ & Academic & 2 & .837 \\
$\mathbf{2}$ & Community characteristics & 3 & .737 \\
$\mathbf{3}$ & Financial & 4 & .810 \\
$\mathbf{4}$ & Non-academic & 2 & .776 \\
$\mathbf{5}$ & Parents characteristics & 2 & .684 \\
$\mathbf{6}$ & Principal characteristics & 2 & .767 \\
$\mathbf{7}$ & School characteristics & 4 & .801 \\
$\mathbf{8}$ & School climate, policies, and org. structure & 4 & .709 \\
$\mathbf{9}$ & Students characteristics & 4 & .698 \\
$\mathbf{1 0}$ & Teachers characteristics & 2 & .819 \\
$\mathbf{1 1}$ & Teachers learning opportunities & 6 & .679 \\
\hline
\end{tabular}

As yielded in table 1, Cronbach's Alpha statistics were applied to ensure the reliability of the data. The overall reliability was calculated at .756 . The reliability of each factor was calculated by the researchers themselves to ensure the reliability of the instrument. After ensuring the reliability of the instrument, the researchers themselves collected final data.

\section{Data Collection Procedures}

The researchers themselves collected the data from the participants through the parallel method. They got permission letters from the heads of the institutions, ensured ethical consideration, and collected the data from participants in their offices. The researchers interviewed 30 parents, purposively selected from the 8 divisions of Punjab. The interviews were audio-recorded and transcribed. Likewise, the results of quantitative parts were interpreted as well.

\subsection{Data Analysis and its Interpretation}

The quantitative data were analyzed by applying an independent sample t-test whereas, the researchers applied thematic analysis technique on the qualitative data.

Table 2: Independent sample t-test on headteachers attitudes towards special schools internal efficacy

\begin{tabular}{ccccccccc}
\hline Sr \# & Categories & \multicolumn{1}{l}{ N } & M & SD & F & df & t & P \\
\hline $\mathbf{1}$ & Urban & 146 & 114.84 & 14.98 & 3.76 & 235 & 1.62 & .057 \\
$\mathbf{2}$ & Rural & 91 & 111.21 & 17.86 & 3.76 &
\end{tabular}

The interpretation of Table 2 yielded that the researchers applied an independent sample t-test to compare rural and urban institutions' head-teachers' attitudes towards special institutions' internal efficacy. The interpretation shows no significant difference between the rural and urban head-teachers attitudes towards their institutions' internal efficacy, $t(237)=$ $1.62, p>.05$. It is estimated that head-teachers of both the rural and urban schools have rated their institutions' internal efficacy at the approximately same level. However a slight difference in the mean was present $(M=114.84, S D=14.98, M=111.21, S D=17.86)$.

The interpretation of Table 3 revealed that the independent sample t-test was applied to measure rural and urban head-teachers attitudes towards their special institutions internal efficacy. The interpretation shows significant difference on rural and urban head-teachers attitudes on factors of financial, $t(235)=1.60, p<.05$, students' perspective, $t(235)=0.45$, $p<.05$, parents characteristics, $t(235)=2.44, p<.05$, community characteristics, $t(235)=$ 3.17 and schools characteristics, $t(235)=1.65, p<.05$. Furthermore, there exist no significant difference between urban and rural head-teachers attitudes towards special schools internal efficacy on factors of teachers characteristics, $t(235)=3.78, p>.05$, principal characteristics, $t(235)=0.31, p>.05$, teachers classes and learning opportunities, $t(235)=$ $2.20, p>.05$, school climate policies and organizational structure, $t(235)=2.56, p>.05$, and non-academic $t(235)=0.31$. 
Table 3: Independent sample t-test on head-teachers' attitudes towards special schools internal efficacy

\begin{tabular}{|c|c|c|c|c|c|c|c|c|c|}
\hline Sr \# & Factors & Locality & $\mathbf{N}$ & $\mathbf{M}$ & SD & $\mathbf{F}$ & Df & $\mathbf{T}$ & $\mathbf{p}$ \\
\hline 1 & Financial & $\begin{array}{l}\text { Urban } \\
\text { Rural }\end{array}$ & $\begin{array}{c}146 \\
91\end{array}$ & $\begin{array}{l}13.79 \\
13.26\end{array}$ & $\begin{array}{l}2.55 \\
2.37\end{array}$ & 1.10 & 235 & 1.60 & 0.29 \\
\hline 2 & Students' perspectives & $\begin{array}{l}\text { Urban } \\
\text { Rural }\end{array}$ & $\begin{array}{c}146 \\
91\end{array}$ & $\begin{array}{l}11.87 \\
11.73\end{array}$ & $\begin{array}{l}1.95 \\
2.38\end{array}$ & 5.35 & 235 & 0.45 & 0.02 \\
\hline 3 & Parents characteristics & $\begin{array}{l}\text { Urban } \\
\text { Rural }\end{array}$ & $\begin{array}{c}146 \\
91\end{array}$ & $\begin{array}{l}5.99 \\
5.51\end{array}$ & $\begin{array}{l}1.62 \\
1.36\end{array}$ & 1.54 & 235 & 2.44 & 0.22 \\
\hline 4 & Community characteristics & $\begin{array}{l}\text { Urban } \\
\text { Rural }\end{array}$ & $\begin{array}{c}146 \\
91\end{array}$ & $\begin{array}{l}11.59 \\
12.57\end{array}$ & $\begin{array}{l}1.95 \\
2.50\end{array}$ & 15.86 & 235 & 3.17 & 0.00 \\
\hline 5 & Schools' characteristics & $\begin{array}{l}\text { Urban } \\
\text { Rural }\end{array}$ & $\begin{array}{c}146 \\
91\end{array}$ & $\begin{array}{l}14.63 \\
14.09\end{array}$ & $\begin{array}{l}2.04 \\
2.65\end{array}$ & 4.54 & 235 & 1.65 & 0.03 \\
\hline 6 & Teachers characteristics & $\begin{array}{l}\text { Urban } \\
\text { Rural }\end{array}$ & $\begin{array}{c}146 \\
91\end{array}$ & $\begin{array}{l}8.28 \\
7.27\end{array}$ & $\begin{array}{l}2.13 \\
1.74\end{array}$ & 3.58 & 235 & 3.78 & 0.06 \\
\hline 7 & Principal characteristics & $\begin{array}{l}\text { Urban } \\
\text { Rural }\end{array}$ & $\begin{array}{c}146 \\
91\end{array}$ & $\begin{array}{l}8.08 \\
8.01\end{array}$ & $\begin{array}{l}1.55 \\
1.57\end{array}$ & 0.29 & 235 & 0.31 & 0.59 \\
\hline 8 & $\begin{array}{c}\text { Teachers, class learning } \\
\text { opportunities }\end{array}$ & $\begin{array}{l}\text { Urban } \\
\text { Rural }\end{array}$ & $\begin{array}{c}146 \\
91\end{array}$ & $\begin{array}{l}24.43 \\
23.30\end{array}$ & $\begin{array}{l}3.92 \\
3.76\end{array}$ & 0.09 & 235 & 2.20 & 0.77 \\
\hline 9 & $\begin{array}{c}\text { Schools' climate, policies \& } \\
\text { organizations }\end{array}$ & $\begin{array}{l}\text { Urban } \\
\text { Rural }\end{array}$ & $\begin{array}{c}146 \\
91\end{array}$ & $\begin{array}{l}15.86 \\
14.66\end{array}$ & $\begin{array}{l}3.45 \\
3.58\end{array}$ & 1.92 & 235 & 2.56 & 0.17 \\
\hline 10 & Academic & $\begin{array}{l}\text { Urban } \\
\text { Rural }\end{array}$ & $\begin{array}{c}146 \\
91\end{array}$ & $\begin{array}{l}8.28 \\
7.27\end{array}$ & $\begin{array}{l}2.13 \\
1.74\end{array}$ & 3.58 & 235 & 3.78 & 0.06 \\
\hline 11 & Non-academic & $\begin{array}{l}\text { Urban } \\
\text { Rural }\end{array}$ & $\begin{array}{c}146 \\
91 \\
\end{array}$ & $\begin{array}{l}8.08 \\
8.01 \\
\end{array}$ & $\begin{array}{l}1.55 \\
1.57\end{array}$ & 0.29 & 235 & 0.31 & 0.59 \\
\hline
\end{tabular}

Figure 2: Descriptive Statics on factors of instructional internal efficacy

\begin{tabular}{|c|c|c|c|}
\hline 二 & Parents characteristics & 1.485 .7 & \\
\hline 은 & Academic & $2.05-7.89$ & \\
\hline a & Teachers characteristics & $2.05 \quad 7.89$ & \\
\hline$\infty$ & Non-academic & $1.56-8.05$ & \\
\hline r & Principal characteristics & $1.56-8.05$ & \\
\hline 6 & Students characteristics & $\begin{array}{ll}2.22 & 11.78\end{array}$ & SD \\
\hline$n$ & Community characteristics & $\begin{array}{ll}2.35 & 12.19\end{array}$ & \\
\hline$\checkmark$ & Financial & 13.59 & \\
\hline m & School characteristics & 14.3 & \\
\hline $\mathrm{a}$ & School climate policies and org. structure & $\begin{array}{ll}3.54 & 15.4\end{array}$ & \\
\hline 一 & Teachers learning opportunities & 24 & \\
\hline
\end{tabular}

As shown in figure 2, results of descriptive statistics were applied to explore maximum perception of internal efficacy of head teachers working in special education institution of different divisions of Punjab. Interpretation reveals that maximum output of head teachers were in favor of teachers learning opportunities $(M=24.00, S D=3.89)$, school climate policies and organizational structure $(M=15.40, S D=3.54)$, School characteristics ( $M$ $=14.30, S D=2.44)$, financial $(M=13.59, S D=2.49)$, community characteristics $(M=12.19$, 
$S D=2.35)$, students characteristics $(M=11.78, S D=2.22)$, principal characteristics $(M=$ 8.05, $S D=1.56)$, non-academic $(M=8.05, S D=1.56)$, teachers characteristics $(M=7.89$, $S D=2.05)$, academic $(M=7.89, S D=2.05)$ and lastly they have viewed that parents characteristics $(M=5.70, S D=1.48)$ are important factor

\subsection{Interpretation of Qualitative Part of data}

The qualitative part of this research was executed by taking interviews from the parents after obtaining their consent. The interviews were edited after transcription. Four major themes have appeared from parents' narratives. The broader themes are presented here.

\section{Theme: 1. School factors}

The first theme that appeared from schools participants' interviews reported that special schools' internal factors like schools' light, electricity, water, and sanitation facilities were strongly reflected in head teachers' managerial abilities. Head-teachers were keenly observing their institutional internal facilities for the sake of their students' better educational and social outcomes.

\section{Theme: 2. Positive attitudes}

All of the parents showed their strong intentions that head-teachers of both rural and urban special education schools have positive attitudes towards their children. Head-teachers met with their children, daily shake hands, and warmly welcome in the schools. If our children feel any difficulty, they feel free to meet with head-teachers and share their problems easily in this regards

\section{Theme: 3. Curricular and co-curricular activities}

Twenty out of twenty parents have reported that head-teachers of rural and urban schools continuously working on the provision of newspaper, musical performance, availability of audio-visual aids, arranging debate and sports for their students, arranging volunteer activities, individual sports activities for our students as well.

\section{Theme 4: parents-teachers meetings}

Sixteen out of twenty parents reported that head-teachers of the schools conduct one meeting with them in a week, in which we sat in airy and furnished rooms, discussing our children's issues. Whereas, four out of twenty participants reported head-teachers of the special school to arrange monthly meetings with them. They further reported that during the meeting, head-teachers give us 10-15 minutes in which we discuss the current situation of our children.

\section{Discussion}

Head-teachers are the pillars of academic institutions. They put their emphasis on the betterment of teachers, students, and their parents. Their attitudes also play an imperative role in the progress of institutions. Special educational institutions are working under the kind control of the Government in which head-teachers are providing their services at their best. The results of the current research established that head-teachers have positive attitudes towards special education institutions' internal efficacy. Moreover, the majority of parents of special schools of these divisions were satisfied from head-teachers' managerial capabilities, their attitudes towards parents, provision of curricular and co-curricular activities, special emphasis on parents-teachers meetings and schools buildings. The results of the current research align with the findings of the research conducted by (Wasal, 2012) whose findings reveal that institutional internal efficacy is a key indicator of head-teachers' performance. The results of the current research stated that head-teachers' attitudes play a significant role in the special institutions' internal efficacy. It is supported with the findings of the research conducted by Davies and Ellison (1997) in the UK whose findings show that head-teachers' performance is an important factor that enhances the internal efficacy of the institutions. Works of national and international scholars have contributed to the existing body of knowledge whose findings reported that head-teachers possess strong attitudes towards institutional better development (Al-Farsi, 2007; Anyagre, 2016; Deakins et al., 2005; DeJaeghere et al., 2009; Eddy-Spicer et al., 2019; Khan et al., 2009; Mwinyipembe \& Orodho, 2014; Sarıçam \& Sakız, 2014). Moreover, the results of this study are also aligned with the findings of the research planned by Adeyemi (2012). The research structured by Yunas (2014) 
in Pakistan, whose results indicated that head-teachers were putting great emphasis on students' quality of education, usage of funds, students' retention, and motivates untrained staff. Furthermore, the work of Yang (2014) supports the findings that head-teachers' attitudes are key indicators to investigate special educational institutional internal efficacy in this regard.

\section{Conclusions}

No one can refuse the importance of education. Likewise, the worth of special education is increasing day by day. Pakistan is running special and general educational institutions for decades. Stakeholders played fewer roles in special educational institutions. Applications of special education increased the option for disabled students which are a neglected part of societies. Teachers disseminate special instruction among students whereas head-teachers put their special intentions for the smooth running of the institutions. In Pakistan, public and private special schools are fulfilling the deficiency of special needs students. The results of the quantitative part show that the head-teachers working in rural and urban special schools have the same attitudes towards their institutions' internal efficacy. The results of the qualitative part established that parents were satisfied with special schools head-teachers managerial capabilities, head-teachers attitudes towards parents, provision of curricular and co-curricular activities, and special emphasis on parents-teachers meetings and schools buildings which indicates that head-teachers working in special education schools were putting their special emphasis on enhancing schools internal efficacy.

There is also a vast spectrum of research to search for some other variables related to attitudes like job performance, time management abilities, or communication skills and seek the relationship of these constructs with internal efficacy. The context of education as an organization opens multifarious prospects to juxtapose internal efficacy with other attitudes among the head-teachers. Accordingly, the internal efficacy of head-teachers should also be examined in connection with other jobs/managerial-related aspects.

\section{References}

Adeyemi, T. O. (2012). School variables and internal efficiency of secondary schools in Ondo State, Nigeria. Journal of Educational and Social Research, 2(3), 205-205.

Adeyemi, T. O., \& Adu, E. T. (2012). Teachers' quality and internal efficiency in primary schools in Ekiti State, Nigeria. American Journal of Economics, 2(5), 87-95.

Adu, E. O., Tadu, R., \& Eze, I. (2012). Teachers' self-efficacy as correlates of secondary school student's academic achievement in southwestern Nigeria. Discovery, 2(4), 8-16.

Adu, E. T. (2010). "School-based variables and internal efficiency of colleges of education in Nigeria" unpublished doctoral dissertation, University of Ado Ekiti, Nigeria.

Ajzen, I. (1985). From intentions to actions: A theory of planned behavior. In Action control (pp. 11-39). Springer, Berlin, Heidelberg.

Ajzen, I. (2015). The theory of planned behavior is alive and well, and not ready to retire: a commentary on Sniehotta, Presseau, and Araújo-Soares. Health psychology review, 9(2), 131-137. https://doi.org/10.1080/17437199.2014.883474

Akram, B., \& Ghazanfar, L. (2014). Self efficacy and academic performance of the students of Gujrat university, Pakistan. Academic Research International, 5(1), 283-290.

Al-Farsi, S. N. (2007). Omani school headteachers views of the effectiveness of school leadership of secondary schools in Oman (Doctoral dissertation, University of Glasgow).

Alrefaei. N. A. (2015). Teachers' sense of efficacy: Examining the relationship of Teacher efficacy and student achievement, published doctoral dissertation in curriculum and instruction, University of Arkansas, USA.

Amaratunga, D., Baldry, D., Sarshar, M., \& Newton, R. (2002). Quantitative and qualitative research in the built environment: Application of "mixed" research approach. Work Study, 51(1), 117-131.

Anyagre, J. T. Z. (2016). Examining the views of teachers and headteachers on supervision and collective school management in contemporary Ghana. International Journal of Innovative Research and Development, 5(10), 99-108.

Ary, D., Jacobs, L. C., \& Sorensen, C. (2010). Introduction to research in education (8th ed.). Boston, USA: Wadsworth, Cengage Learning.

Avramidis, E., Bayliss, P., and Burden, R. (2000). A survey into mainstream teachers' attitudes towards the inclusion of children with special educational needs in the ordinary school in 
one local education authority. Educational Psychology, 20, 1910-211. https://doi.org/ $10.1080 / 713663717$

Babbie, E. (2007). The practice of social research (11th ed.). Belmont, CA: Thompson Wadsworth.

Bandura, A. (1978). Self-efficacy: Toward a unifying theory of behavioral change. Advances in Behaviour Research and Therapy, 1(4), 139-161 https://doi.org/10.1016/01466402(78)90002-4

Bandura, A. (2007). Much ado over a faulty conception of perceived self-efficacy grounded in faulty experimentation. Journal of Social and Clinical Psychology, 26, 641-658. https://doi.org/10.1521/jscp.2007.26.6.641

Berger, J. (2020). The catalyst: How to change anyone's mind, Simon Schuster, New York.

Best, J. W., \& Kahn, J. V. (2006). Research in education (10th ed.). Boston: Pearson.

Bizer, G. Y., Barden, J, C., Petty, R, E. (2003). Attitudes. Encyclopedia of cognitive science. London: Nature Publishing Group.

Brown, S. R., Durning, D. W., \& Selden, S. C. (2008). Q methodology, In K. Yang \& G. J. Miller (Eds.). Handbook of research methods in public administration (2nd ed., pp. 721-763). New York: Taylor \& Francis.

Bryman, A. (2016). Social research methods (5th ed.). Oxford: Oxford University Press.

Cohen, L., Manion, L., \& Morrison, K. (2018). Research methods in education (8th ed.). Routledge.

Creswell, J. W. \& Creswell, J. D. (2018). Research design: Qualitative, quantitative, and mixed methods approach (5th ed.). Thousand Oaks, CA: Sage.

Davies, B., \& Ellison, L. (1997). Teachers' perceptions of school quality and effectiveness: improving schools using staff attitude surveys. International Journal of Educational Management, 11(5), 222-228

Dawson, C. (2009). A practical guide to research methodology (4th ed.). UK: How to Books.

Deakins, D., Glancey, K., Menter, I., \& Wyper, J. (2005). Enterprise education: The role of headteachers. The International Entrepreneurship and Management Journal, 1(2), 241263.

DeJaeghere, J. G., Williams, R., \& Kyeyune, R. (2009). Ugandan secondary school headteachers' efficacy: What kind of training for whom?. International Journal of Educational Development, 29(3), 312-320.

Eddy-Spicer, D., Bubb, S., Earley, P., Crawford, M., \& James, C. (2019). Head teacher performance management in England: Balancing internal and external accountability through performance leadership. Educational Management Administration \& Leadership, 47(2), 170-188.

Fraenkel, J. R., Wallen, N. E., \& Hyun, H., H. (2019). The nature of qualitative research. How to design and evaluate research in education (10th ed.). Boston: McGraw Hill.

Gay, L. R., Mills, G. E., \& Airasian, P. W. (2009). Educational research: Competencies for analysis and applications, student value edition. Upper Saddle River, NJ: Merrill.

Gil-Flores, J., Rodríguez-Santero, J., \& Torres-Gordillo, J. J. (2017). Factors that explain the use of ICT in secondary-education classrooms: The role of teacher characteristics and school infrastructure. Computers in Human Behavior, 68, 441-449.

Hassan, M. U., Nawaz, H., \& Faiz, A. U. H. (2021). Revealing the effects of teachers stimulating technological inclusion on university students' educational gains: A comparative study. Humanities \& Social Sciences Reviews, 9(3), 986-999. https://doi.org/10.18510/hssr.2021.9397

Heiskala, L., Erola, J., \& Kilpi-Jakonen, E. (2021). Compensatory and multiplicative advantages: Social origin, school performance, and stratified higher education enrolment in Finland. European Sociological Review, 37(2), 171-185.

Hopman, J. A. B., Tick, N. T., van der Ende, J., Wubbels, T., Verhulst, F. C., Maras, A., et al. (2018). Special education teachers' relationships with students and self-efficacy moderate associations between classroom-level disruptive behaviors and emotional exhaustion. Teach. Teach. Educ. 75, 21-30. https://doi.org/ 10.1016/j.tate.2018.06.004

Iqbal, M. (2012). Essentials of educational administration. Sarhad University of science and information technology, unpublished documents, Peshawar, Pakistan.

Islam, A. (2019). Parent-teacher meetings and student outcomes: Evidence from a developing country. European Economic Review, 111, 273-304.

Ismail, Z., Basheer, I., and Khan, J. H. (2016). Teachers' attitudes towards inclusion of special needs children into primary level mainstream schools in Karachi. The European Journal 
of Social \& Behavioural Sciences, 17, 2177-2196. https://doi.org/10.15405/ejsbs.195

Johnson, R. B., \& Christensen, L. (2016). Educational research: Quantitative, qualitative, and mixed approaches (6th ed.). London: Sage

Johnson, R. B., \& Onwuegbuzie, A. J. (2004). Mixed methods research: A research paradigm whose time has come. Educational Researcher, 33(7), 14-26. https://doi.org/10.3102/0013189X033007014

Khan, S. H., Saeed, M., \& Fatima, K. (2009). Assessing the performance of secondary school headteachers: A survey study based on teachers' views in Punjab. Educational Management Administration \& Leadership, 37(6), 766-783.

Kim, A. (2004). Parent-school partnership formation through the school council in Korea. Educational Research for Policy and Practice, 3(2), 127-139.

Kin, T. M., \& Kareem, O. A. (2016). Teacher attitudes toward change: a comparison between high-and mediocre-performing secondary schools in Malaysia. International Studies in Educational Administration, 44(1), 105-128.

Kulshrestha, A. K., \& Pandey, K. (2013). Teachers training and professional competencies. Voice of research, 1(4), 29-33.

Maxwell, J., \& Loomis, D. (2003). Mixed methods design: An alternative approach. In A. Tashakkori \& C. Teddlie (Eds.), Handbook of mixed methods in social and behavioural research (pp. 241-272). Thousand Oaks, CA: Sage.

Mwinyipembe, M. M., \& Orodho, A. J. (2014). Effectiveness of quality assurance and standards officers school supervisory roles in enhancing students' academic performance in national examinations in Nakuru District, Kenya. Journal of Education and Practice, 5(16), 69-80.

Polit, D. F., Beck, C. T., \& Hungler, B. P. (2001). Essentials of nursing research: Methods, appraisal and utilization. (5th ed.). Lippincott Williams \& Wilkins.

Praisner, C. L. (2003). Attitudes of elementary school principals toward the inclusion of students with disabilities. Except. Child. 69, 135-145. https://doi.org/ $10.1177 / 001440290306900201$

Punch, K. F. (2013). Introduction to social research: Quantitative and qualitative approaches (3rd ed.). London: Sage.

Sarıçam, H., \& Sakız, H. (2014). Burnout and teacher self-efficacy among teachers working in special education institutions in Turkey. Educational Studies, 40(4), 423-437.

Singh, K. (2007). Quantitative social research methods. New Delhi, ND: Sage.

Teddlie, C., \& Yu, F. (2007). Mixed methods sampling: A typology with examples. Journal of Mixed Methods Research, 1(1), 77-100. https://doi.org/10.1177/1558689806292430

Vakola, M., \& Nikolaou, I. (2005). Attitudes towards organizational change: what is the role of employees' stress and commitment? Employee Relations, 27(2), 160-174

Vaz, S., Wilson, N., Falkmer, M., Sim, A., Scott, M., Cordier, R., et al. (2015). Factors associated with primary school teachers' attitudes towards the inclusion of students with disabilities. PLoS One 10(8), e0137002. https://doi.org/10.1371/journal.pone.0137002

Wasal, K. (2012). Factors promoting excellence in schools, unpublished doctoral dissertation, faculty of education, arts and social sciences, Sarhad University of Science and Information Technology, Peshawar-Pakistan

Yang, K. (2014). Factors affecting internal efficiency of primary schools in Nuer zone of Gambella regional state, unpublished Master of Arts thesis in educational leadership, institute of education and professional development studies, department of educational planning and management, Jimma, University, Ethiopia

Yunas, M. (2014). Developing a framework for promoting internal efficiency of secondary schools, unpublished doctoral dissertation, faculty of arts, social sciences and education, Sarhad University of science and information, technology, PeshawarPakistan.

Zahid, M. (2020). Comparative study of internal efficacy of public and private special education institutions in the Punjab, unpublished doctoral dissertation, Institute of Special Education, University of the Punjab Lahore, Pakistan.

Zahid, M., \& Ashraf, S. (2020). Perceptions of special education teachers on the internal efficacy of their institutions: A comparative study. Review of Economics and Development Studies, 6(4), 811-820. 